Studia Kinanthropologica, XIX, 2018, (3), 147-157

The Scientific Journal for Kinanthropology

FYZIOLOGICKÉ, BIOCHEMICKÉ A VÝKONNOSTNÍ ZMĚNY U ADOLESCENTNÍCH BĚŽCŮ VLIVEM 10-DENNÍHO TRÉNINKOVÉHO KEMPU V 1040 M N. M.

\title{
PHYSIOLOGICAL, BIOCHEMICAL AND PERFORMANCE CHANGES TO A 10-DAYS TRAINING CAMP AT 1040 M ALTITUDE IN ADO- LESCENT RUNNERS
}

\author{
P. Bahenský \& R. Malátová
}

Jihočeská univerzita v Českých Budějovicích, Pedagogická fakulta, Katedra tělesné výchovy a sportu

\begin{abstract}
The study examined fifty subjects (26 girls and 24 boys), at the age of $16.6 \pm 1.4$, with the average weight of $57.9 \pm 9.2 \mathrm{~kg}$ and the height of $171.5 \pm 8,5 \mathrm{~cm}$. Forty probands participated in a ten-day training camp at the altitude of 1,040 $\mathrm{m}$ a.s.l. The objective of the present paper is to verify the effect of a training camp on selected functional, biochemical parameters and level of their performance. The control group comprised ten runners, who underwent training in the altitude of $400 \mathrm{~m}$ a.s.l.. No significant changes of values incurred in members of the control group. At a intervention group, heart rate values significantly decreased by $4.05 \%$. Long acclimatization is not necessary to be able to train at altitude $1000 \mathrm{~m}$. After return $\mathrm{VO}_{2}$ max values significantly increased by $4.02 \%$, pulse oxygen by $3.62 \%$ and relative work rate at the moment $\mathrm{VO}_{2}$ max by $3.15 \%$. The parameter of Wingate test was insignificantly increased by $1.31-3,27$. The level of aerobic threshold significantly improved by $4.45 \%$, anaerobic threshold significantly progressed by $3.98 \%$. Blood parametres no significantly rose by $1.10-1.25 \%$. Even though the values determined fail to accomplish the effect of a training at higher altitudes, the training described in the present paper might be a suitable alternative for endurance sportsmen, especially for young athletes. Training cannot fully substitute training at higher altitude, performance effect is self-evident.
\end{abstract}

Keywords: training camp; moderate altitude; oxygen uptake; lactate; blood count

\section{SOUHRN}

Studie se zúčastnilo padesát probandů (26 dívek a 24 chlapců) ve věku $16,6 \pm 1,4$ let, s průměrnou hmotností $57,9 \pm 9,2 \mathrm{~kg}$ a tělesnou výškou $171,5 \pm 8,5 \mathrm{~cm}$. Čtyřicet probandů se zúčastnilo desetidenního tréninkového kempu v nadmořské výšce 1040 metrů nad mořem. Cílem bylo ověřit vliv kempu na jejich funkční, biochemické parametry a úroveň jejich trénovanosti. Deset probandů tvořilo kontrolní skupinu, která absolvovala trénink v místě bydliště v nadmořské výšce $400 \mathrm{~m} \mathrm{n}$. m. U nich nedošlo $\mathrm{k}$ významné změně žádných sledovaných hodnot. U intervenční skupiny došlo po kempu k významnému snížení hodnot srdeční frekvence o 4,05\%. Trénink v $1000 \mathrm{~m} \mathrm{n}$. m. nevyžaduje dlouhou aklimatizaci. Po návratu došlo $\mathrm{k}$ významnému zvýšení hodnot $\mathrm{VO}_{2} \max$ o 4,02\%, tepového kyslíku o $3,62 \%$ a relativního výkonu při $\mathrm{VO}_{2} \max$ o $3,15 \%$. Hodnoty Wingate testu nevýznamně narostly o 1,31-3,27 \%. Hodnoty úrovně aerobního prahu byly významně zlepšeny o $4,45 \%$, u anaerobního prahu byl významný progres o 3,98 \%. Krevní parametry byly nevýznamně navýšeny o 1,10-1,25\%. Efekt kempu není plně srovnatelný s pobytem ve vyšší nadmořské výšce, přesto by mohl být jeho vhodnou alternativou pro vytrvalostní sportovce, zejména pro mladé. Pobyt ve vyšší nadmořské výšce plně nenahradí, ale výkonnostní efekt je prokazatelný.

Klíčová slova: soustředění; stř̌ední nadmořská výška; spotřeba kyslíku; laktát; krevní obraz 


\section{Úvod}

Význam př́pravy ve vyšší nadmořské výšce je znám již dlouho, systematický výzkum začal ale až v rámci př́pravy na XIX. OH v Mexiku, které probíhaly v nadmořské výšce okolo $2200 \mathrm{~m}$ (Saunders, Pyne, \& Gore, 2009). Dle většiny odborníků je nejvhodnější klasifikace nadmořské výšky: nízká (do 800 m n. m.), střední (do 1500 m n. m.), vyšší (1500-3000 m n. m.) a vysoká (nad 3000 m n. m.). Za optimální nadmořskou výšku pro vytrvalostní trénink je považována výška okolo $2000 \mathrm{~m} \mathrm{n}$. m. (Wilber, 2004; Noakes, 2003; Gore et al., 2001). U nižší nadmořské výšky není prokázán efekt na krvetvorbu, proto není tato výška dle některých autorů pro vytrvalostní trénink vrcholových sportovců doporučována (Wilbert, 2001; Saunders et al., 2004) ani v dostupné literatuře podrobně popsána. Pouze Wachsmuth et al. (2013) uvádí, že po 3-týdenním kempu ve výšce $1360 \mathrm{~m} \mathrm{n}$. m. došlo u plavců $\mathrm{k}$ významnému navýšení množství hemoglobinu. Stray-Gundersen, Chapman, \& Levine (2001), Robach et al., (2006) a dalšś autoři uvádí nadmořskou výšku 1200-1400 m n. m. jako lokalitu vhodnou pro využití v jedné z variant vysokohorského tréninku: v modelu žít nahoře $(2500 \mathrm{~m} \mathrm{n}$. m.) a trénovat dole (1200-1400 m n. m.). V tréninkovém procesu platí, že v čím vyšší nadmořské výšce probíhá trénink, tím je větší riziko přetrénování. Proto je nutné průběžně přizpůsobovat trénink aktuálnímu stavu organismu (Suchý, 2012).) Fu et al., (2007) ve své metaanalýze mj. uvádějí, že efekt tréninku je závislý na objemu, intenzitě a individuálnímu přizpůsobení zatížení absolvovaném v průběhu tréninkového kempu.

Tolerance k vysoké nadmořské výšce je individuální (Chapman, Stray-Gundersen, \& Levine, 1998). Opakované pobyty ve vyšší nadmořské výšce mají pozitivní vliv na délku a průběh aklimatizace (Neumann, Pfützner, \& Berbalk, 2013). Jednou z možností monitorování průběhu aklimatizace je prostřednictvím měření ranní srdeční frekvence (SF). Po příjezdu do vyšší nadmořské výšky dochází $\mathrm{k}$ nárůstu hodnot ranní SF, po ukončení aklimatizace tato hodnota opět postupně klesá (Suchý, 2012; Bahenský \& Suchý, 2015). Z důvodu postupného urychlení adaptačních procesů je vhodné začít s pobyty ve vyšší nadmořské výšce již v adolescentním věku. Problematikou tréninku mladých běžců ve vyšší nadmořské výšce se zabývají např. Buchheit et al. (2012), Saltin et al. (1995) nebo Bahenský a Suchý (2015). Podobným výzkumným souborem se zabýval i Suchý (2012) či Suchý a Opočenský (2015), kteři testovali mladé lyžaře v dorosteneckém a juniorském věku. Friedmann et al. (2005) zkoumali vliv vyšší nadmořské výšky na mladé plavce. Odborníci se shodují, že organismus mladých běžců reaguje citlivěji na změny parciálního tlaku kyslíku. Pahud (1986) doporučuje mladým sportovcům, kvůli horší snášenlivosti vyšší nadmořské výšky, trénink v zhruba poloviční nadmořské výšce, než dospělým. Suchý (2012) uvádí názory českých trenérů běžeckého lyžování, kteří doporučují jako dostačující pro adaptaci u mládežnických kategorií tréninkové pobyty ve výšce 1000 až $1400 \mathrm{~m} \mathrm{n}$. m, sám autor se přiklání $\mathrm{k}$ tréninku ve výšce $1200 \mathrm{~m}$ až $1400 \mathrm{~m}$ n. m., která by měla posloužit pro postupnou adaptaci na vyšší nadmořskou výšku. Mezi lokality, ve kterých běžci zařazení do mládežnických reprezentačních výběrů ČR absolvovali v posledních 15 letech tréninkové kempy, patří: Melago (1890 m n. m.), Strbské Pleso (1350 m n. m.), Zadov (1090 m n. m.), Krkonoše - Dvorská bouda (1320 m n. m.). Až na Melago se jedná o lokality řazené do střední nadmořské výšky.

Za efektivní tréninkový pobyt ve vyšší nadmořské výšce je považován 3-4 týdenní tréninkový kemp (Levine \& Stray-Gundersen, 1997; Heinicke, Heinicke, Schmidt, \& Wolfarth, 2005). U vrcholových sportovců se opakují takto dlouhé pobyty ve vyšší nadmořské výšce dle možností, někteří běžci v této výšce žijí celý život, jiní se do ní stěhují trvale (Suchý, 2012). Ne každý sportovec může absolvovat takto dlouhý pobyt, at již z důvodů organizačních, finančních či jiných. V literatuře je popsán i efekt zkráceného pobytu ve vyšší nadmořské výšce o délce kratší než dva týdny, např. Diebel, Newhouse, Thompson, a Johnson (2017), Suchý (2012), Svedenhag, Saltin, Johansson, a Kaijser (1991), Bahenský a Suchý (2015) či Suchý a Opočenský (2015). Z těchto studií vyplývá, že i zkrácený tréninkový pobyt ve vyšší nadmořské výšce může mít pozitivní efekt na funkční a biochemické parametry a na sportovní výkonnost vytrvalostních sportovců. Tento efekt ale nedosahuje efektu 3-4 týdenního pobytu.

Největší význam vysokohorské př́ípravy spočívá v nárůstu transportní kapacity krve pro kyslík $\mathrm{k}$ pracujícím svalům. Z řady různých ukazatelů krevního obrazu je pro potřeby ř́zení tréninkového procesu ve vyšší nadmořské výšce vhodné sledovat především počet červených krvinek, hladinu hemoglobinu a hodnotu hematokritu (Suchý, 2012). Hematologické změny mohou značně zvýšit $\mathrm{VO}_{2} \max$ (maximální spotřebu kyslíku) organismu díky zlepšení kapacity krve pro přenos kyslíku k pracujícím svalům. Tím se zvyšuje aerobní výkon (Dill \& Adams, 1971; Marconi, Marzorati, \& Cerretelli, 2006; 
Maciejczyk, Sudoł, \& Szyguła, 2012). $\mathrm{VO}_{2}$ max je základní předpoklad vytrvalostního výkonu, což je potvrzeno řadou studií, které nacházejí vysoce signifikantní vztahy mezi spotřebou kyslíku vztaženou na kg hmotnosti a vytrvaleckým výkonem (Astrand \& Rodahl, 1986; Bunc, 1989; Dengel, Flynn, Costill, \& Kirwan, 1989; O'Toole \& Douglas, 1995). Bonetti a Hopkins (2009) ve své metaanalýze uvádějí, že díky efektu tréninku ve vyšší nadmořské výšce sportovci mohou zlepšit svou výkonnost přibližně o $5,2 \%$ v porovnání s přípravou v nížině. Další možností, jak sledovat úroveň speciálních vytrvalostních schopností je stanovení laktátových prahů, nejčastěji se využivají anaerobní práh (ANP) a aerobní práh (AEP). U specifického zatížení při testování nacházíme těsnou vazbu mezi intenzitou zatížení na úrovni ANP a závodním výkonem. Invazivní stanovení ANP probíhá na základě změn koncentrace laktátu nebo parametrů acidobazické rovnováhy v krvi při stoupajícím zatížení (Bunc, 1989). Původní koncepce laktátového ANP stanovovala ANP pomocí koncentrace laktátu v krvi odpovídající koncentraci LA $=4 \mathrm{mmol} / 1$ (Mader \& Hollmann, 1977).

Při vysokohorském tréninku by měl převažovat trénink nižší intenzity (tím více, čím je vyšší nadmořská výška), který nemá významný vliv na rozvoj $\mathrm{VO}_{2} \max$ (Neumann, Pfützner, \& Berbalk, 2013). $\mathrm{VO}_{2}$ max je sice základním ukazatelem výkonnosti u vytrvalostních běžců, ale není jediným. Také je potřeba brát v úvahu ekonomiku pohybu (Bunc, 2012; Saunders et al., 2004). Její ovlivnění je možné mj. silovým tréninkem (Støren, Helgerud, Støa, \& Hoff, 2008). Millet, Jaouen, Borrani, a Candau (2002) ve své studii prokázali vliv silového tréninku zaměřeného na sílu dolních končetin (zejména čtyřhlavý sval stehenní a lýtkové svaly) na výkonnost prostřednictvím změny ekonomiky běhu. K přirozenému posilování dolních končetin dochází také při tréninku v horském kopcovitém terénu.

Nejčastěji jsou v našich podmínkách tréninkové kempy ve vyšší nadmořské výšce využivány v podzimním přípravném období (polovina října až polovina listopadu) a v jarním přípravném období (duben až začátek května). V přípravě na vrcholné mezinárodní závody je využíván model s návratem ze soustředění cca 21 dnů před vrcholným závodem, což odpovídá období optimální výkonnosti, samozřejmě s možnými individuálními odlišnostmi (Popov, 1994; Suslov, 1994; Wachsmuth et al., 2013).

\section{Cíl}

Cílem této práce ověřit, zda desetidenní tréninkový kemp ve výšce okolo $1000 \mathrm{~m}$ n. m. má vliv na výkonnost a funkční změny organismu sportovců a zda je pro adolescentní běžce částečnou alternativou k pobytu ve vyšší nadmořské výšce.

\section{Metodika}

\section{Soubor probandi}

Studie se zúčastnilo padesát probandů-běžců na střední a dlouhé tratě v adolescentním věku, přičemž čtyřicet účastníků výzkumu, z toho 21 dívek ve věku 16,7 $\pm 1,5$ let, s průměrnou hmotností 56,8 $\pm 7,3 \mathrm{~kg}$ a tělesnou výškou $168,5 \pm 5,7 \mathrm{~cm}$ a 19 chlapců ve věku $16,5 \pm 1,6$ let, s průměrnou hmotností $60,3 \pm 10,5 \mathrm{~kg}$ a tělesnou výškou 175,8 $\pm 10,2 \mathrm{~cm}$ se zúčastnilo jednoho ze tří desetidenních soustředění v nadmořské výšce 1040 m n. m. na Nových Hutích na Šumavě v termínu 17. - 26. 10. 2014, 22. 10. - 1. 11. 2015 a 21. - 30. 10. 2016. Deset probandů tvořilo kontrolní skupinu, z toho pět dívek ve věku $16,7 \pm 0,7$ let, s průměrnou hmotností $53,8 \pm 9,5 \mathrm{~kg}$ a tělesnou výškou $166,0 \pm 6,0 \mathrm{~cm}$ a pět chlapců ve věku 16,5 $\pm 1,0$ let, s průměrnou hmotností $57,4 \pm 8,4 \mathrm{~kg}$ a tělesnou výškou $173,0 \pm 3,7 \mathrm{~cm}$. Prvního tréninkového kempu se zúčastnilo třináct probandů, druhého kempu patnáct, třetího dvanáct. Všichni testovaní probandi již měli zkušenost se srovnatelnými tréninkovými kempy. Tréninkový program byl v každém roce totožný. Tréninkové zatížení respektuje individuální výkonnostní úroveň. Všichni sledovaní probandi jsou účastníci mistrovství republiky, šestnáct z nich získalo medaili na mládežnickém mistrovství republiky.

Všichni probandi měli za sebou tři týdny systematické př́ípravy na další sezónu, předtím šest týdnů závodního období. Trénink na soustředění plynule navazoval na předchozí trénink. První dva dny soustředění probandi absolvovali tréninky nižší intenzitou, než jsou zvyklí. Zařazen byl pouze běh nízkou intenzitou, turistika, rovinky a běh na úrovni AEP, postupně byly zakomponovány tréninky o větší intenzitě i objemu. Změnou v obsahu tréninku na soustředění oproti tréninku před kempem bylo absolvování pěti tréninkových jednotek turistiky. Po návratu ze soustředění následoval volnější mikrocyklus z pohledu objemu i intenzity, všichni probandi měli totožnou tréninkovou náplň. 
Členové kontrolní skupiny absolvovali trénink v místě bydliště, tzn. v nadmořské výšce $400 \mathrm{~m}$ n. m. v rovinaté lokalitě. Absolvovali stejné tréninkové zatížení jako členové intervenční skupiny, s výjimkou pěti tréninkových jednotek chůze, kterou nahradili volným během o délce $4-6 \mathrm{~km}$.

\section{Protokol}

Z důvodu snahy získání dat od co nejvyššího počtu probandů jsme provedli stejné testování tři roky po sobě se zachováním stejné stavby tréninku i obsahu a načasování testování. Stejná testování absolvovali probandi účastnící se intervence i kontrolní skupina, všichni ve stejném termínu. Termíny testování před tréninkovým kempem byl bezprostředně před odjezdem. Z organizačních důvodů testování probíhalo ve dvou dnech, vždy ve stejném pořadí testů jako po návratu ze soustředění. Druhý test jsme provedli 8-10 dnů po návratu ze soustředění, což koresponduje s ukončením druhé fáze reaklimatizace (Dick, 1992; Wachsmuth et al., 2013; Wilber, 2004). Přestože se naše studie nezabývá vysokohorským tréninkem, chtěli jsme dodržet stejnou metodiku pro případné následné srovnání dat. U fyziologických testů byly zjištěny u děvčat a chlapců významně odlišné hodnoty, z důvodu objektivního stanovení významnosti změny jsme přistoupili k vyhodnocení změn zvlášt u děvčat a zvlášt u chlapců.

Pro ověření stanovených cílů byly sledovány následující parametry:

1. Měření ranní klidové srdeční frekvence - probandi měřili a zaznamenávali 15 dnů před soustředěním, v průběhu soustředění a po dobu 15 dnů po ukončení soustředění ranní SF pomocí přístroje Polar 3000. Měřeno bylo dle následující metodiky: po probuzení si sportovci sami nasadili sporttester a zaznamenali nejnižší SF v průběhu následujících 3 minut.

2. Dynamika změn anaerobního a aerobního prahu - byl opakovaně proveden test $4 \times 1600 \mathrm{~m}$ na stadionu s pauzou 2 minuty s měřením laktátu pomocí přístroje Lactate Scout+ od firmy EKF, u nějž výrobce udává možnou chybu měření $3 \%$. Rychlosti běhu byly stanoveny takto: 1. úsek rychlostí nižší než odpovídá aerobnímu prahu (AEP), 2. úsek v rozmezí mezi aerobním a anaerobním prahem (ANP), 3. úsek na úrovni anaerobního prahu a 4. úsek rychleji, než anaerobní práh. Aerobní a anaerobní práh byly stanoveny na základě stupňovaného zátěžového testu uskutečněného před prvním laktátovým testem. Zjištěné hodnoty jsme zpracovali prostřednictvím programu Winlactat s využitím exponenciální funkce. Hodnotu rychlosti běhu na úrovni AEP a ANP uvádíme v jednotkách $\mathrm{km} \cdot \mathrm{h}^{-1}$. Všechna měření byla absolvována $\mathrm{v}$ nadmořské výšce $400 \mathrm{~m}$, jeden den před odjezdem na soustředění a deset dnů po návratu.

3. Dynamika změn maximální spotřeby kyslíku $\left(\mathrm{VO}_{2} \mathrm{max}\right)$ - maximální funkční parametry byly zjištovány na bicyklovém ergometru pomocí stupňovaného zatížení do „vita maxima”. Po začátečním rozehřátí byla intenzita zátěže zvyšována o $20 \mathrm{~W}$ každou minutu až do okamžiku přerušení testu samotným probandem. Respirační parametry byly měřeny pomocí přístroje Metalyzer 3B od firmy Cortex. Posuzováno bylo: maximální relativní spotřeba kyslíku $\left(\mathrm{VO}_{2} \mathrm{max} \cdot \mathrm{kg}^{-1}\right)$, tepový $\mathrm{kyslík}\left(\mathrm{VO}_{2} \cdot \mathrm{SF}^{-1}\right) \mathrm{a}$ relativní výkon při $\mathrm{VO}_{2} \max \left(\mathrm{WR} \cdot \mathrm{kg}^{-1}\right)$. Testy jsme provedli jeden den před odjezdem na soustředění a devět dnů po návratu.

4. Dynamika změn rychlostně silových dispozic - měřeno Wingate testem. Test se provádí na bicyklovém ergometru, data byla zpracována pomocí Load Ergometry Manager. Posuzovali jsme maximální výkon, nejvyšší $5 \mathrm{~s}$ výkon a průměrný 30 s výkon. Po pětiminutovém rozehřátí na bicyklu probandi absolvovali 30s „all out” test. Testování proběhlo tři dny před odjezdem na tréninkový kemp a devět dnů po návratu z kempu.

5. Vybrané parametry krevního obrazu - tři dny před soustředěním a čtvrtý den po návratu jsme u všech sledovaných provedli rozbor krve na stanovení množství:

- hemoglobinu $\left[\mathrm{g} \cdot \mathrm{l}^{-1}\right]$

- hematokrit [poměr erytrocytů k objemu krve ve zkoumaném vzorku]

- počet erytrocytů $\left[\right.$ tera $\left.\cdot 1^{-1}\right]$

Odběry byly realizovány vždy ve stejnou dobu spolupracující sportovní lékařkou v akreditované biochemické a hematologické laboratoři na Poliklinice Jih v Českých Budějovicích. 


\section{Statistická analýza}

Věcnou významnost rozdílů sledovaných veličin jsme stanovili pomocí Cohenova koeficientu $d$, použili jsme hodnocení dle Hendla (2004), který doporučuje:

- $d>0,8$ vyjadřuje velký účinek

- hodnota $d \mathrm{v}$ intervalu $0,5-0,8$ vyjadřuje středně velký účinek

- hodnota $d$ v intervalu $0,2-0,5$ vyjadřuje malý účinek

- $d<0,2$ vypovídá o slabém účinku

U parametrů, kde jsou naměřené hodnoty u chlapců a dívek významně odlišné, jsme věcnou významnost posuzovali zvlášt.

Též jsme zjištovali statistickou významnost rozdílu středních hodnot sledovaných veličin pomocí parametrického párového t-testu pro dva závislé výběry. $\mathrm{S}$ ohledem na charakter výzkumu jsme se rozhodli posuzovat statistickou významnost rozdílů na hladině významnosti $(\mathrm{p})<0,05$.

Provedený výzkum byl prováděn se souhlasem Etické komise PF JU, č. j.: 001/2018. Všichni účastníci, u nezletilých i jejich rodiče signovali informovaný souhlas.

\section{V'́sledky}

Během desetidenního pobytu byli běžci ubytování v nadmořské výšce $1040 \mathrm{~m}$ n. m., většinu tréninků absolvovali v nadmořské výšce $1060 \mathrm{~m} \mathrm{n}$. m., kde se věnovali především rozvoji obecné vytrvalosti, tempa běhu na úrovni aerobního a anaerobního prahu. Při volných bězích a turistice se pohybovali v rozmezí 920 až $1218 \mathrm{~m} \mathrm{n}$. m. V tabulce 1 je uveden tréninkový plán po dobu soustředění v roce 2014, v ostatních letech byl totožný. Členové kontrolní skupiny absolvovali stejné tréninkové zatížení, s výjimkou turistiky. Všechny tréninky, s výjimkou vybíhaných kopců, byly u kontrolní skupiny absolvovány bez převýšení. Naproti tomu účastníci soustředění na Šumavě absolvovali $85 \%$ naběhaných kilometrů v kopcovitém terénu (kontrolní skupina pouze $8 \%$ ). V porovnání s tréninkem před soustředěním došlo k nárůstu objemu tréninku o tři tréninkové jednotky za 10 dnů.

Tabulka 1./ Table 1.

Absolvovaná tréninková náplň./ Realized training program.

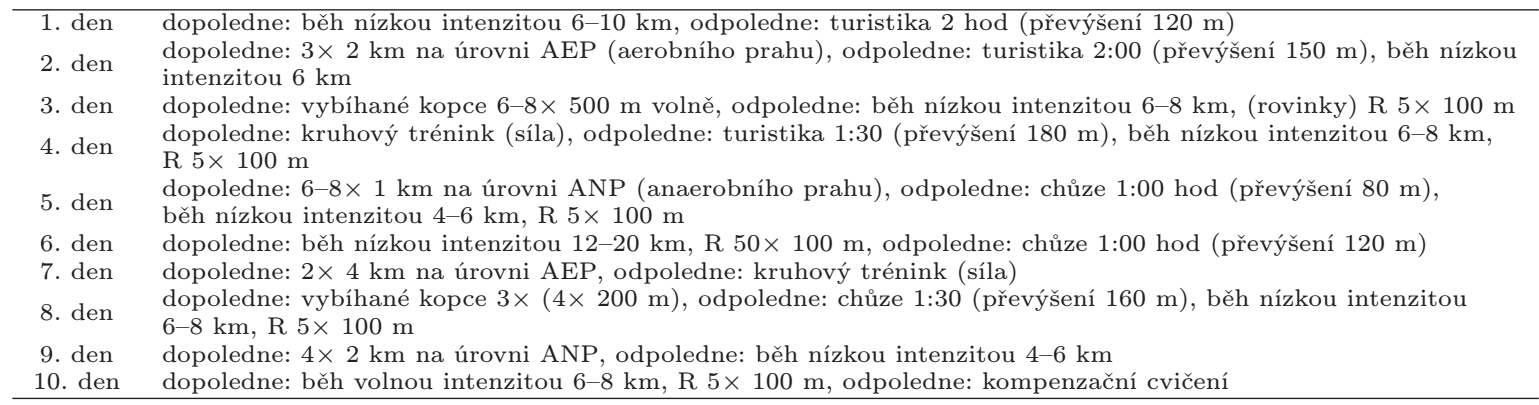

Tabulka 2./ Table 2.

Změna klidové srdeční frekvence./ Changes of heart rate at rest.

\begin{tabular}{cccc}
\hline & před soustředěním & na soustředění & po soustředění \\
\hline počet dnů & 15 & 10 & 15 \\
účastníci kempu & $51,7 \pm 5,2$ & $52,0 \pm 5,1$ & $49,6 \pm 5,5$ \\
kontrolní skupina & $50,3 \pm 4,6$ & $50,0 \pm 4,0$ & $50,1 \pm 4,6$ \\
\hline
\end{tabular}

Hodnoty srdeční frekvence se v průběhu pobytu na tréninkovém kempu průměrně zvýšily o $0,61 \%$ $(\mathrm{d}=0,05)$ oproti hodnotám před soustředěním (viz tabulka 2$)$, tato změna není věcně ani statisticky významná. Po návratu ze soustředění se průměrně snížily o $4,05 \%(\mathrm{~d}=0,39)$ oproti hodnotě před soustředěním. Tato změna je věcně (s malým efektem) a statisticky významná. U kontrolní skupiny 
nedošlo $\mathrm{k}$ věcně ani statisticky významné změně srdeční frekvence. $\mathrm{V}$ průběhu sledování došlo $\mathrm{k}$ jejímu snížení o $0,46 \%(\mathrm{~d}=0,05)$ oproti hodnotě před soustředěním.

V tabulce 3 jsou uvedeny hodnoty maximální spotřeby kyslíku. Po návratu z tréninkového kempu byl zaznamenán průměrný nárůst hodnot o $4,02 \%$ ( $\mathrm{u}$ chlapců $\mathrm{d}=0,28 ; \mathrm{u}$ děvčat $\mathrm{d}=0,58$ ). $\mathrm{U}$ hodnot tepového kyslíku došlo k průměrnému nárůstu o 3,62 \% ( $\mathrm{u}$ chlapců $\mathrm{d}=0,09 ; \mathrm{u}$ děvčat $\mathrm{d}=0,30$ ), hodnota relativního výkonu při $\mathrm{VO}_{2} \max (\mathrm{WR}$ ) se průměrně zvýšila o $3,15 \%$ (u chlapců d $=0,36$; $\mathrm{u}$ děvčat $\mathrm{d}=0,27)$. Změna relativního výkonu při $\mathrm{VO}_{2} \max$, hodnoty $\mathrm{VO}_{2} \max \mathrm{u}$ chlapců a tepového kyslíku u děvčat jsou věcně významné s malým efektem, $\mathrm{VO}_{2}$ max u děvčat se středně velkým efektem. Změna všech tří parametrů je statisticky významná. U kontrolní skupiny nedošlo k věcně ani statisticky významné změně, hodnota $\mathrm{VO}_{2} \max$ se průměrně zvýšila o $0,68 \%$ (chlapci $\mathrm{d}=0,08$; dívky $\mathrm{d}=0,03$ ), hodnota tepového kyslíku o 0,91 \% (chlapci d =0,06; dívky d =0,12) a hodnota WR o 0,19 \% (chlapci $\mathrm{d}=0,09 ;$ dívky $\mathrm{d}=0,04)$.

Tabulka 3./ Table 3.

Změna hodnot spiroergometrických parametrů./ Change of values of spiroergometry parameters.

\begin{tabular}{ccccccc}
\hline & $\mathrm{VO}_{2} \max \left(\mathrm{ml} \cdot \mathrm{min}^{-1} \cdot \mathrm{kg}^{-1}\right)$ & $\mathrm{VO}_{2} \cdot \mathrm{SF}^{-1}$ & $\left(\mathrm{ml} \cdot \mathrm{min}^{-1}\right)$ & \multicolumn{2}{c}{$\mathrm{WR}\left(\mathrm{W} \cdot \mathrm{kg}^{-1}\right)$} \\
\hline & 2 dny před & 9 dnů po & 2 dny před & 9 dnů po & 2 dny před & 9 dnů po \\
\hline účastníci kempu & $55,0 \pm 7,8$ & $57,1 \pm 7,9$ & $17,3 \pm 4,6$ & $17,9 \pm 4,7$ & $4,48 \pm 0,56$ & $4,61 \pm 0,57$ \\
kontrolní skupina & $56,6 \pm 8,9$ & $57,0 \pm 9,1$ & $19,7 \pm 5,0$ & $19,8 \pm 4,7$ & $4,33 \pm 0,99$ & $4,34 \pm 1,00$ \\
\hline
\end{tabular}

Ve Wingate testu došlo u parametru relativní průměrný 30s výkon k průměrnému nárůstu o 1,31 \% ( $\mathrm{u}$ chlapců $\mathrm{d}=0,25 ; \mathrm{u}$ děvčat $\mathrm{d}=0,13$ ). U relativního maximálního $5 \mathrm{~s}$ výkonu je průměrný nárůst o 2,64 \% (u chlapců $\mathrm{d}=0,13 ; \mathrm{u}$ děvčat $\mathrm{d}=0,27$ ) a u relativního maximálního výkonu o $3,27 \%$ ( $\mathrm{u}$ chlapců $\mathrm{d}=0,16 ; \mathrm{u}$ děvčat $\mathrm{d}=0,24$ ). Nárůst těchto hodnot je na pomezí slabého a malého účinku věcné významnosti, statisticky významný je jen u relativního maximálního $5 \mathrm{~s}$ výkonu a relativního průměrného 30s výkonu. U kontrolní skupiny se hodnoty věcně ani statisticky významně nezměnily, u relativního průměrného 30 s výkonu došlo k průměrnému nárůstu o $0,34 \%$ (u chlapců i u děvčat $\mathrm{d}=0,06)$, u relativního maximálního 5 s výkonu o $0,40 \%(\mathrm{u}$ chlapců $\mathrm{d}=0,05 ; \mathrm{u}$ děvčat $\mathrm{d}=0,03) \mathrm{a}$ u relativního maximálního výkonu o $0,56 \%$ ( $\mathrm{u}$ chlapců $\mathrm{d}=0,11$; u děvčat $\mathrm{d}=0,00$ ).

Tabulka 4./ Table 4.

Změna parametrů zjištěných Wingate testem./ Changes of parameters determined by Wingate test.

\begin{tabular}{ccccccc}
\hline & $\begin{array}{c}\text { relativní průměrný 30s výkon } \\
\left(\mathrm{W} \cdot \mathrm{kg}^{-1}\right)\end{array}$ & $\begin{array}{c}\text { relativní maximální výkon } \\
\left(\mathrm{W} \cdot \mathrm{kg}^{-1}\right)\end{array}$ & $\begin{array}{c}\text { relativní maximální 5s výkon } \\
\left(\mathrm{W} \cdot \mathrm{kg}^{-1}\right)\end{array}$ \\
\hline & 2 dny před & 9 dnů po & 2 dny před & 9 dnů po & 2 dny před & 9 dnů po \\
\hline účastníci kempu & $8,10 \pm 0,89$ & $8,20 \pm 0,89$ & $11,43 \pm 1,97$ & $11,76 \pm 2,05$ & $9,63 \pm 1,68$ & $9,86 \pm 1,70$ \\
kontrolní skupina & $8,09 \pm 0,88$ & $8,14 \pm 1,01$ & $11,34 \pm 1,48$ & $11,41 \pm 1,50$ & $9,55 \pm 1,28$ & $9,60 \pm 1,33$ \\
\hline
\end{tabular}

Tabulka 5./ Table 5.

Změna hodnoty anaerobního a aerobního prahu./ Changes of values of anaerobic and aerobic thresholds.

\begin{tabular}{ccccc}
\hline & \multicolumn{2}{c}{ AEP $\left(\mathrm{km} \cdot \mathrm{h}^{-1}\right)$} & \multicolumn{2}{c}{ ANP $\left(\mathrm{km} \cdot \mathrm{h}^{-1}\right)$} \\
\hline & 1 den před & 10 dnů po & 1 den před & 10 dnů po \\
\hline účastníci kempu & $12,20 \pm 1,43$ & $12,75 \pm 1,61$ & $13,62 \pm 1,56$ & $14,16 \pm 1,73$ \\
kontrolní skupina & $13,04 \pm 1,92$ & $13,14 \pm 1,96$ & $14,23 \pm 2,10$ & $14,36 \pm 2,12$ \\
\hline
\end{tabular}

Změna hodnot úrovně aerobního a anaerobního prahu je prezentována v tabulce 5 . AEP byl zlepšen průměrně o $4,45 \%$ ( $\mathrm{u}$ chlapců $\mathrm{d}=0,56$; $\mathrm{u}$ děvčat $\mathrm{d}=0,36)$, u ANP byl progres průměrně o $3,98 \%$ ( $\mathrm{u}$ chlapců $\mathrm{d}=0,51$; $\mathrm{u}$ děvčat $\mathrm{d}=0,42$ ). $\mathrm{V}$ jednotkách min $\cdot \mathrm{km}^{-1}$ jsme zaznamenali zlepšení rychlosti běhu na úrovni aerobního prahu o 0:11,0 a u anaerobního prahu o 0:10,0. Změna obou veličin 
byla věcně i statisticky významná, z pohledu věcné významnosti došlo u chlapců ke středně velkému účinku u děvčat $\mathrm{k}$ účinku malému. Změna hodnot u kontrolního souboru nebyla věcně ani statisticky významná, u AEP byl zaznamenán průměrný nárůst o 0,79 \% ( u chlapců d = 0,08; u děvčat d = 0,14), u ANP o $0,92 \%$ (u chlapců $\mathrm{d}=0,11 ; \mathrm{u}$ děvčat $\mathrm{d}=0,17$ ).

V tabulce 6 jsou uvedeny průměrné hodnoty krevních testů, množství erytrocytů bylo 10 dnů po soustředění průměrně o $1,17 \%$ vyšší oproti vzorku před soustředěním (chlapci $\mathrm{d}=0,06$; dívky $\mathrm{d}=0,33$ ). U hemoglobinu došlo $\mathrm{k}$ nárůstu průměrně o $1,10 \%$ (chlapci $\mathrm{d}=0,09$; dívky $\mathrm{d}=0,32$ a $\mathrm{u}$ hematokritu průměrně o $1,25 \%$ (chlapci $\mathrm{d}=0,00$; dívky $\mathrm{d}=0,49$ ). Změny krevních hodnot nejsou statisticky významné, u děvčat jsou věcně významné s malým efektem, u chlapců změny věcně významné nejsou. U kontrolní skupiny nedošlo k věcně ani statisticky významné změně. Množství erytrocytů se průměrně zvýšilo o $0,15 \%$ ( $u$ chlapců $d=0,01, u$ děvčat $d=0,07$ ), $u$ hemoglobinu byl zaznamenán průměrný nárůst o $0,09 \%(\mathrm{~d}=0,01)$ a u hematokritu došlo k poklesu průměrně o $0,20 \%$ (u chlapců $\mathrm{d}=-0,23 ; \mathrm{u}$ děvčat $\mathrm{d}=0,18)$.

Tabulka 6./ Table 6.

Změny hodnot krevnich testü./ Changes of blood test values.

\begin{tabular}{|c|c|c|c|c|c|c|}
\hline účastníci kempu & \multicolumn{2}{|c|}{ erytrocyty $\left(\right.$ tera $\left.\cdot 1^{-1}\right)$} & \multicolumn{2}{|c|}{ hemoglobin $\left(g \cdot \mathrm{l}^{-1}\right)$} & \multicolumn{2}{|c|}{ hematokrit (erytrocyty $\cdot$ objem krve ${ }^{-1}$ ) } \\
\hline kontrolní vzorek & $4,793 \pm 0,308$ & $4,799 \pm 0,298$ & $142,2 \pm 8,8$ & $142,3 \pm 8,3$ & $0,419 \pm 0,015$ & $0,418 \pm 0,015$ \\
\hline
\end{tabular}

\section{Diskuze}

Z našich dat vyplývá, že aklimatizace v nadmořské výšce okolo $1000 \mathrm{~m} \mathrm{n}$. m. nevyžaduje v plném rozsahu aklimatizaci nezbytnou pro pobyt ve vyšších nadmořských výškách, což je v souladu s publikovanými informacemi (Suchý, 2012). U hodnot ranní klidové srdeční frekvence po př́jezdu na soustředění nedošlo k významnému nárůstu (výška tréninkového kempu není příliš rozdílná od nadmořské výšky trvalého pobytu probandů), po návratu z tréninkového kempu ale došlo k významnému snížení hodnot ranní klidové $\mathrm{SF}$, srovnatelným s desetidenními pobyty ve vyšší nadmořské výšce (Suchý, 2012). To potvrzuje pozitivní vliv tréninkového kempu.

Desetidenní tréninkový pobyt ve výšce okolo $1000 \mathrm{~m} \mathrm{n}$. m. nemá přesvědčivě významný vliv na vybrané krevní parametry, to je v souladu s publikovanými daty (Bonetti \& Hopkins, 2009). V naší studii jsme ale zjistili nárůst množství erytrocytů, hemoglobinu a hematokritu u probandů účastnících se tréninkového kempu na horách, ale pouze u děvčat jsme zaznamenali významnou změnu. Nezjištovali jsme vliv menzes na naměřené hodnoty, proto nelze dělat jednoznačné závěry. V̌̌echny změny jsou v rozmezí 1,10-1,25\%, tyto hodnoty nedosahují většiny hodnot zjištěných u pobytů ve vyšší nadmořské výšce. Publikované nárůsty množství hemoglobinu v důsledku tréninkového pobytu ve vyšší nadmořské výšce se nejčastěji v dostupné literatuře pohybují v rozmezí 3,6-9 \% (Daniels \& Oldridge, 1970; Berglund et al., 2002; Heinicke et al., 2005; McLean et al., 2013; Suchý, 2012). U kontrolního vzorku došlo pouze k zanedbatelným změnám hodnot krevního obrazu.

Přestože na začátku podzimního přípravného období nedochází v tréninku k rozvoji anaerobní složky běžeckého tréninku, hodnota $\mathrm{VO}_{2} \max$ se po absolvování tréninkového kempu u účastníků intervence, na rozdíl od kontrolního souboru, významně zvýšila. Nárůst o 4,05 \% není srovnatelný s $10 \%$ zlepšením při trvalém pobytu ve vysoké nadmořské výšce (Burtscher, Nachbauer, Baumgartl, \& Philadelphy, 1996; Marconi et al., 2006) či zlepšení o 9,6 \% (Brugniaux et al., 2006) po absolvování 18-denního tréninkového kempu ve vysoké nadmořské výšce (šest dnů ve $2500 \mathrm{~m} \mathrm{n}$. m. a dvanáct dnů ve výšce $3000 \mathrm{~m} \mathrm{n.} \mathrm{m.)} \mathrm{a} \mathrm{tréninku} \mathrm{ve} \mathrm{výšce} 1200 \mathrm{~m} \mathrm{n.} \mathrm{m.} \mathrm{(varianta} \mathrm{tréninku} \mathrm{LHTL} \mathrm{-} \mathrm{living} \mathrm{high,} \mathrm{training}$ low). Námi zjištěná data jsou ale překvapivě srovnatelná s dalšími studiemi. Dill a Adams (1971) uvádějí po tréninkovém kempu 17 dnů dlouhém absolvovaném v nadmořské výšce $3090 \mathrm{~m}$ n. m. zlepšení $\mathrm{VO}_{2} \max$ u mládežnických běžců o 4,2 \%, Levine \& Stray-Gundersen (1997) ve své studii uvádějí zlepšení $\mathrm{VO}_{2} \max$ o $5 \%$ po čtyřtýdenním tréninkovém kempu, kdy probandi bydleli ve výšce $2500 \mathrm{~m} \mathrm{n}$. $\mathrm{m}$. a trénovali ve výšce 1300-1400 m n. m. S nárůstem hodnot $\mathrm{VO}_{2}$ max částečně koresponduje i nárůst hodnot tepového kyslíku. 
Dynamikou AEP a ANP se zabýval např. Suchý (2012), který zjistil statisticky i věcně významné zlepšení těchto parametrů po desetidenním pobytu mladých lyžařu - běžců v nadmořské výšce 1800 m n. m., u jednotlivých prahů nárůst až o 9,3%. Bahenský \& Suchý (2015) došli k podobným výsledkům (zlepšení ANP o 4,6 \%) i u sedmidenního pobytu atletů běžců v nadmořské výšce $1880 \mathrm{~m}$ n. m. V naší studii jsme zaznamenali zlepšení rychlosti běhu na úrovni AEP o 4,45 \% a zlepšení rychlosti běhu na úrovni ANP o 3,98 \%, což se blíží publikovaným změnám vlivem zkráceného pobytu ve vyšší nadmořské výšce. V porovnání s kontrolním vzorkem, kdy došlo ke zlepšení o 0,79 \% u AEP a o 0,92 \% u ANP, je zřejmé, že námi zvolený tréninkový pobyt na Šumavě významně ovlivnil trénovanost adolescentních atletů běžců.

U rychlostně silových dispozic (testovaných Wingate testem) jsme zjistili nárůst hodnot na pomezí významnosti, přestože tréninkové prostředky, které by přímo rozvíjely tyto dispozice, nebyly na kempu používány, s výjimkou jednoho tréninku vybíhaných kopců $200 \mathrm{~m}$ dlouhých (jeden z celkových dvaceti tréninků). Pravděpodobně se projevil vliv přirozeně rozvíjené síly prostřednictvím pohybu v kopcovitém terénu. Zlepšení jsme zaznamenali i u kontrolní skupiny běžců, ale nárůst hodnot o 0,34 až $0,56 \%$ je zanedbatelný.

Došlo ke zvýšení silových schopností. Naše zjištění vyplývá sice z nespecifického testu pro běžce, ale ukazuje, že při tréninku v horském prostředí dochází k významnému zvýšení síly dolních končetin, které významně koreluje s nárůstem výkonnosti. Předpokládáme, že díky zlepšení síly dolních končetin došlo ke zlepšení $\mathrm{VO}_{2} \max$ i ekonomiky pohybu, což má pozitivní vliv na výkonnost, to potvrdili ve své práci též Chromiak a Mulvaney (1990), kteří prezentovali, že souběžný trénink síly a vytrvalosti může pozitivně ovlivnit výkonnost vytrvalostních sportovců. Brugniaux et al. (2006) prezentují nárůst výkonu při $\mathrm{VO}_{2} \max$ po osmnáctidenním pobytu ve vysokohorském prostředí o 8,1 \% (LHTL - pobyt šest dnů v $2500 \mathrm{~m} \mathrm{n}$. m., poté dvanáct dnů ve $3000 \mathrm{~m} \mathrm{n.} \mathrm{m.} \mathrm{a} \mathrm{tréninku} \mathrm{ve} \mathrm{výšce} 1200 \mathrm{~m}$ n. m.). Těchto hodnot naše výsledky nedosahují, zlepšení o 3,15 \% je ale významné. Souběžný rozvoj vytrvalosti a síly má u běžců vliv na zlepšení výkonnosti, to je v souladu s publikovanými výsledky (Millet et al., 2002; Støren et al., 2008).

Námi popisovaný tréninkový kemp je zkrácený a navíc v nižší nadmořské výšce, než je uváděno jako efektivní pro nárůst potřebných funkčních a biochemických parametrů. Přesto jsme zjistili relativně překvapivé výsledky. Pobyt v nadmořské výšce okolo $1000 \mathrm{~m} \mathrm{n}$. m. (při výškovém rozdílu $600 \mathrm{~m}$ od nadmořské výšky v místě trvalého bydliště) může být pro adolescentní běžce podnětný. Protože zlepšení krevních parametrů nekoresponduje s nárůstem trénovanosti, je pravděpodobný ještě vliv jiné proměnné, pravděpodobně tréninku v kopcovitém terénu, kdy jsou stimulovány silové schopnosti. Naše zjištění potvrzují i výsledky kontrolní skupiny. Vždy, včetně použití střední nadmořské výšky, ale platí, že je nezbytně přípravu individualizovat a použít přiměřený objem a intenzitu zatížení.

\section{Závěr}

Funkční a biochemické změny vlivem desetidenního tréninkového pobytu v nadmořské výšce okolo $1000 \mathrm{~m}$ n. m. nedosahují hodnot dosažených po delších pobytech ve vyšší nadmořské výšce. U některých parametrů však došlo $\mathrm{k}$ významnému nárůstu hodnot a u některých byly zaznamenány srovnatelné změny se zkrácenými pobyty ve vyšší nadmořské výšce. Výhodou tréninkového kempu v nadmořské výšce okolo 1000 m n. m. je, že nevyžaduje dlouhou aklimatizaci, z důvodu malého rozdílu výšky trvalého pobytu a výšky tréninkového kempu. V této výšce také není zvýšené riziko přetrénování. Aktivace srdečně cévního systému i výsledky funkčních testů naznačují, že i zkrácený pobyt na tuzemských horách v nadmořské výšce okolo 1000 m může vyvolat významné změny funkčních parametrů a nevýznamné změny krevních parametrů. Ty by mohly být způsobeny kombinací zvýšené nadmořské výšky (o $600 \mathrm{~m}$ ) a přirozeným rozvojem síly při tréninku v kopcovitém terénu, ve kterém běžci absolvují trénink. Tento kemp by mohl být využitelný především u mladých, začínajících sportovců, v případech nedostatku potřebných prostředků či absence časových možností cestovat do vyšší nadmořské výšky ze vzdálenějších lokalit, či při nedostatku času na absolvování 3-4 týdenního tréninkového kempu. Tréninkový pobyt v nižších nadmořských výškách je určitou alternativou k pobytu ve vyšší nadmořské výšce, přestože jej plně nenahradí. Mưže být alternativou ke zkrácenému tréninkovému pobytu ve vyšší nadmořské. 


\section{Literatura}

Astrand, P. O., \& Rodahl, K. (1986). Textbook of work physiology. 3rd ed. New York: McGraw Hill Book Co.

Bahenský, P., \& Suchý, J. (2015). Vliv sedmidenního tréninkového kempu ve vyšší nadmořské výšce na vybrané funkční a biochemické parametry mladých běžců. Studia Sportiva, 9(1), 63-72.

Berglund, B., Gennser, M., Örnhagen, H., Östberg, C., \& Wide, L. (2002). Erythropoietin concentrations during 10 days of normobaric hypoxia under controlled environmental circumstances. Acta Physiol Scand, 174, 225-229.

Bonetti, D. L., \& Hopkins, W. G. (2009). Meta-analysis of sea level performance following adaptation to hypoxia. Sports Medicine, 39, 107-127.

Brugniaux, J. V., Schmitt, L., Robach, P., Nicolet, G., Fouillot, J. P., Moutereau, S., ... \& Cornolo, J. (2006). Eighteen days of „living high, training low" stimulate erythropoiesis and enhance aerobic performance in elite middle-distance runners. Journal of Applied Physiology, 100(1), 203-211.

Buchheit, M., Kuitunen, S., Voss, S. C., Williams, B., Mendez-Villanueva, A., \& Bourdon, P. C. (2012). Physiological strain associated with high-intensity hypoxic intervals in highly trained young runners. Journal of Strength \& Conditioning Research, 26(1), 94-106.

Bunc, V. (1989). Biokybernetický př́stup $k$ hodnocení reakce organismu na tělesné zatǐzení. Praha: VÚT UK.

Bunc, V. (2012). Kvantitativní a kvalitativní diagnostika ve hrách. Hry 2012, 7.

Burtscher, M., Nachbauer, W., Baumgartl, P., \& Philadelphy, M. (1996). Benefits of training at moderate altitude versus sea level training in amateur runners. European journal of applied physiology and occupational physiology, $74(6), 558-563$.

Daniels, J., \& Oldridge, N. (1970). The effects of alternate exposure to altitude and sea level on world-class middle-distance runners. Medicine Science in Sports, 2, 107-112.

Dengel, D. R., Flynn, M. G., Costill, D. L., \& Kirwan, J. P. (1989) Determinants of success during triathlon competition. Res. Quart. Exerc. Sport, 60, 234-238.

Dick, F. W. (1992). Training at altitude in practice. International journal of sports medicine, 13(1), 203-205.

Diebel, S. R., Newhouse, I., Thompson, D. S., \& Johnson, V. B. (2017). The effects of a 10-day altitude training camp at 1828 meters on varsity cross-country runners. International journal of exercise science, $10(1), 97$.

Dill, D. B., \& Adams, W. C. (1971). Maximal oxygen uptake at sea level and at 3,090-m altitude in high school champion runners. Journal of Applied Physiology, 30(6), 854-859.

Friedmann, B., Frese, F., Menold, E., Kauper, F., Jost, J., \& Bärtsch, P. (2005). Individual variation in the erythropoietic response to altitude training in elite junior swimmers. British journal of sports medicine, 39(3), 148-153.

Fu, Q., Townsend, N. E., Shiller, S. M., Martini, E. R., Okazaki, K., Shibata, S., ... \& Levine, B. D. (2007). Intermittent hypobaric hypoxia exposure does not cause sustained alterations in autonomic control of blood pressure in young athletes. American Journal of Physiology-Regulatory, Integrative and Comparative Physiology, 292(5), 1977-1984.

Gore, C., Hanhn, A. G., Aughey, R. J., Martin, D. T., Ashenden, M. J., \& Clark, S. A. (2001). Live high:train low increases muscle buffer capacity and submaximal cycling efficiency. Acta Physiol. Scand., $173(3), 275-286$.

Heinicke, K., Heinicke, I. Schmidt, W., \& Wolfarth, B. (2005). A three-week traditional altitude training increase hemoglobin mass and red cell volume in elite biathlon athletes. Int J Sports Med, 26 (5) 350-355.

Hendl, J. (2004). Přehled statistických metod zpracování dat. Analýza a metaanalýza dat. Praha: Portál.

Chapman, R. F., Stray-Gundersen, J., \& Levine, B. D. (1998). Individual variation in response to altitude training. Journal of applied physiology, 85(4), 1448-1456.

Chromiak, J. A., \& Mulvaney, D. R. (1990). A review: The effects of combined strength and endurance training on strength development. The Journal of Strength 8 Conditioning Research, 4(2), 55-60. 
Levine, B. D., \& Stray-Gundersen, J. (1997). „Living high-training low”: effect of moderate-altitude acclimatization with low-altitude training on performance. Journal of applied physiology, 83(1), 102-112.

Maciejczyk, M., Sudoł, G., \& Szyguła Z. (2012). Influence of hypoxia training on the aerobic capacity of an elite race walker. Human movement, 13(4), 360-366.

Mader, A., \& Hollmann, W. (1977). Zur Bedeutung der Stoffwechselleistungsfähigkeit des Eliteruderers in Training und Wettkampf. Leistungssport, 9, 8-62.

Marconi, C., Marzorati, M., \& Cerretelli, P. (2006). Work capacity of permanent residents of high altitude. High altitude medicine $\&$ biology, 7(2), 105-115.

McLean, B. D., Buttifant, D., Gore, C. J., White, K., Liess, C. \& Kemp, J. (2013). Physiological and Performance Responses to a Preseason Altitude-Training Camp in Elite Team-Sport Athletes. International Journal of Sports Physiology and Performance, 8, 391-399.

Millet, G. P., Jaouen, B., Borrani, F., \& Candau, R. (2002). Effects of concurrent endurance and strength training on running economy and VO2 kinetics. Medicine $\mathcal{E}$ Science in Sports $\&$ Exercise, $34(8), 1351-1359$.

Neumann, G., Pfützner, A., \& Berbalk, A. (2013). Optimiertes Ausdauertraining. Meyer \& Meyer Verlag.

Noakes, T. (2003). Lore of Running (4th edition). Champaign, IL: Human Kinetics.

O'Toole, M. L., \& Douglas, P. S. (1995) Applied physiology of triathlon. Sports Med, 19(4), 251-267.

Pahud, F. (1986). Training at altitude: general principles and personal experience. New studies in athletics, 3, 53-57.

Popov, I. (1994). The pros and cons of altitude training. In New Studies in Athletics, IAAF, 2, $15-21$.

Robach, P., Schmitt, L., Brugniaux, J. V., Nicolet, G., Duvallet, A., Fouillot, J. P., ... Richalet, J. P. (2006). Living high-training low: effect on erythropoiesis and maximal aerobic performance in elite Nordic skiers. European journal of applied physiology, 97(6), 695-705.

Saltin, B., Larsen, H., Terrados, N., Bangsbo, J., Bak, T., Kim, C. K., Svedenhag, J., \& Rolf, C. J. (1995). Aerobic exercise capacity at sea level and altitude in Kenyan boys, junior and senior runners compared with Scandinavian runners. Scandinavian Journal of Medicine ES Science in Sports, 5(4), 209-221.

Saunders, P. U., Pyne, D. B., \& Gore, CH. J. (2009). Endurance Training at Altitude. High Altitude $\&$ Biology, $10(2)$.

Saunders, P. U., Telford, R. D., Pyne, D. B., Cunningham, R. B., Gore, C. J., Hahn, A. G., \& Hawley, J. A. (2004). Improved running economy in elite runners after 20 days of simulated moderatealtitude exposure. Journal of Applied Physiology, 96(3), 931-937.

Støren, Ø., Helgerud, J. A. N., Støa, E. M., \& Hoff, J. A. N. (2008). Maximal strength training improves running economy in distance runners. Medicine $\&$ Science in Sports $\&$ Exercise, 40(6), $1087-1092$.

Stray-Gundersen, J., Chapman, R. F., \& Levine, B. D. (2001). „Living high-training low” altitude training improves sea level performance in male and female elite runners. Journal of applied physiology, $91(3), 1113-1120$.

Suchý, J. (2012). Využití hypoxie a hyperoxie ve sportovním tréninku. Praha: Karolinum.

Suchý, J., \& Opočenský, J. (2015). Usefulness of training camps at high altitude for well-trained adolescents. Acta Gymnica, 45(1), 13-20.

Suslov, F. P. (1994). Basic principles of training at high altitude. In New Studies in Athletics, IAAF, $2,45-49$.

Svedenhag, J., Saltin, B., Johansson, C., \& Kaijser, L. (1991). Aerobic and anaerobic exercise capacities of elite middle-distance runners after two weeks of training at moderate altitude. Scandinavian Journal of Medicine 65 Science in Sports, 1(4), 205-214.

Wachsmuth, N. B., Völzke, C., Prommer, N., Schmidt-Trucksäss, A., Frese, F., Spahl, O., ... \& Schmidt, W. (2013). The effects of classic altitude training on hemoglobin mass in swimmers. European journal of applied physiology, 113(5), 1199-1211.

Wilber, R. L. (2001). Current trends in altitude training. Sports Medicine, 31 (4), 249-265. 
Wilber, R. L. (2004). Altitude training and athletic performance. Champaign: Human Kinetics.

PhDr. Petr Bahenský, Ph.D.

KTVS PF JU

Na Sádkách 2/1

37005 České Budějovice

pbahensky@pf.jcu.cz 